\title{
Dating for the wired generation
}

\section{A match made in silicon.}

\section{Stephen Gaskell}

First there was Gloria. I met her through a dating agency called Heaven Scent. They were big on smells. You know when you sniff your lover's hair and get all soppy and light-headed? Do you think it's because there's something innately appealing about their particular blend of Head and Shoulders and sweat?

Didn't think you did.

What's really going on is that you're testing your and your partner's disease-defence compatibility. Apparently the make-up of your personal aroma (or 'funk' as is the case) is a pointer to the subtleties of your immunological system. Get a bad combination and your darling cherubs are going to grow up as sickly little mites not even able to stave off the common cold. And who wants a snivelling brat twentyfour seven?

So, anyway, the testing kit arrived at the office, and half-an-hour later a chemical signature of yours truly, strapped to a Lycraclad courier, made its way back to Heaven Scent's labs.

The next day I checked my inbox and, lo and behold, they'd found me a match! They even attached her profile and a pic. Gloria was smart and cute - as well of great olfactory promise. That evening, I showered and shaved - taking care not to hide my approved scent under a swathe of deodorant - and headed out for dinner. As soon as we met I knew she wasn't the one. She was a Chanel belle - drenched in the most nauseous perfume imaginable. And she had a caustic personality to match. Heaven sent? Dream on!

Next came Lucy. Lucy was on Perfect Balance's books. They're a dating website who place their faith in facial symmetry. They reckon that we're most attracted to those whose physiognomy matches our own. Being a man whose face looks like a grizzly bear's, I had my doubts. I did the mug-shots, anyhow - it only took five minutes in front of my workstation's webcam.
When Lucy approached my table at Starbucks, my first thought was that she was a guy looking for directions to the gents. Then I did a double-take and thought I was looking in the mirror. I know we're told to love ourselves, but that was taking the mantra too far. A double-mocha latte later, and I was outta there.

Perseverance, I said to myself, is the key. I went to Avatar Matchmakers - virtually. They've got offices in Sim-London. Here's the deal: you make a personality profile, give your physical stats, and then they create an online version of your- self - a homunculus

in machine code.

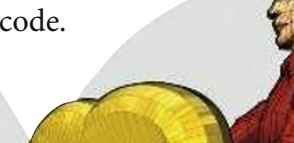

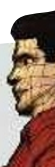

I guess we're our own worst judges. The date ended badly. I'm just glad she was drinking iced - rather than hot - coffee when she threw her drink over me.

Still, I couldn't stop myself. Might as well try them all, I thought. Vocal harmony matching struck a chord with Beverly. Traumatic life-event compatibility threw me in with Kate. Biorhythm affinity coaxed me into a date with Pritha. All were disasters.

Next I tried the Wicked Ways Dating Emporium. They matched partners through their MQ - their Morality Quotient. The theory being that we're attracted to those who are just as bad - or good - as ourselves. In a historical free-for-all, Jesus would've got paired with Mother Theresa, whereas Hitler would've smooched with, well, Eva Braun, I guess.

My MQ was 95. A little less virtuous than average. Bad enough to hit on my ex's cousin. Not bad enough to hit on my ex's sister. I got Jasmin.

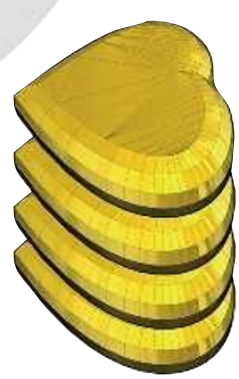

"So you're the bad boy," she said, looking me up and down as we greeted each other outside the Casa Blanca Tapas Bar.

"And you're the bad girl." I grinned. Mis-

This virtual-you then breezes around SimLondon trying to find love with the other virtual bods. When it finds a match, the real you in the real world goes and meets the man, or woman, behind the ones and noughts. It's a genius idea. Minimal effort, maximum encounters. You can even watch your future date's virtual-self going about his or her business just to make sure they're your type. The realism of these avatars is incredible. When virtual-me found virtual-Sally I thought I'd found the one.

Boy, was I mistaken. Virtual-Sally and real-Sally couldn't have been more different. Virtual-Sally goofed around, cracked jokes, and had a lot of class. Real-Sally moved like a marionette, jabbered on and on, and couldn't have been more rude to the barista who served us.

She said I didn't live up to her expectations either. chief was this girl's middle name. Or so I thought.

At dinner we ordered nearly every dish on the menu, and stuffed ourselves silly. Several bottles of vintage Rioja helped to loosen our tongues. It was a great date - until it was time to leave.

Jasmin leaned close and eyed the door, "Ever skipped on the bill?"

Before I could answer she was halfway across the restaurant, napkins scattering in her wake. The girl was evil. I couldn't run on a dinner bill. I slumped back in my chair, defeated.

That was the last straw. Bring on the Luddites. I'm going to a bar.

Stephen Gaskell is currently taking an MSc in evolutionary and adaptive systems at the University of Sussex, UK. He recently sold his first story to Writers of the Future Volume XXIII. 